EDITORIAL

Volume 10 Issue 12018

DOI: 10.21315/eimj2018.10.1.1

ARTICLE INFO

Submitted: 01-03-2018

Accepted: 20-03-2018

Online: 30-03-2018

\section{Strengthening Education in Medicine Journal Through Collaboration with Malaysian Association of Education in Medicine and Health Science (MAEMHS)}

\author{
Muhamad Saiful Bahri Yusoff', Yong Rafidah Abdul Rahmann, ${ }^{2,3}$, Fazlina \\ Mohamed Rouse ${ }^{4}$ \\ ${ }^{1}$ Editor in Chief, Education in Medicine Fournal, School of Medical \\ Sciences, Universiti Sains Malaysia, Kelantan, MALAYSIA \\ ${ }^{2}$ President, Malaysian Association of Education in Medicine and \\ Health Science, Kuala Lumpur, MALAYSIA \\ ${ }^{3}$ Faculty of Medicine, Cyberjaya University College of Medical Sciences, \\ Selangor, MALAYSIA \\ ${ }^{4}$ Head of Fournal Division, Penerbit Universiti Sains Malaysia, Pulau \\ Pinang, MALAYSIA
}

To cite this article: Yusoff MSB, Abdul Rahman YR, Mohamed Rouse F. Strengthening Education in Medicine fournal through collaboration with Malaysian Association of Education in Medicine and Health Science (MAEMHS). Education in Medicine Journal. 10(1):1-2. https://doi.org/10.21315/ eimj2018.10.1.1

To link to this article: https://oi.org/10.21315/eimj2018.10.1.1

CORRESPONDING AUTHOR

Dr. Muhamad Saiful Bahri Yusoff, Department of Medical Education, School of Medical Sciences, Universiti Sains Malaysia, 16150 Kota Bharu, Kelantan, Malaysia | Email: msaiful_bahri@usm.my

The Education in Medicine fournal (EIMJ) was first published in 2009 by the School of Medical Sciences, Universiti Sains Malaysia. The peer reviewed journal serves as an international platform to disseminate information related to medical and allied health education. The journal has been consistently improving its performance, namely in terms of frequency, visibility, number and quality of articles (1-4) - as summarised in Table 1.

In recognition of the journal's improved performance, since 2016 EIMJ is published by Penerbit Universiti Sains Malaysia, the official publisher of Universiti Sains Malaysia, creating a more stable publishing environment. Thus, ensuring that high quality research is disseminated to the widest possible audience through various content delivery format initiatives including PDF and EPUB while remains fully openaccessed.

In yet another important and significant milestone, Universiti Sains Malaysia and Malaysian Association of Education in Medicine and Health Sciences (MAEMHS) will jointly publish EIMJ beginning 2018. Collaborative efforts between both organisations will pave the way for the journal's advancement in the region.

We hope these efforts will boost visibility and credibility of EIMJ as a reputable academic journal and able to attract the best quality of submission. The journal's editorial team members are doing their best to ensure the change process occurs smoothly with the least turbulence. 
Table 1: Profiling of EIMJ ${ }^{a}$

\begin{tabular}{lccccc}
\hline \multicolumn{1}{c}{ Item } & $\mathbf{2 0 1 3}$ & $\mathbf{2 0 1 4}$ & $\mathbf{2 0 1 5}$ & $\mathbf{2 0 1 6}$ & $\mathbf{2 0 1 7}$ \\
Number of submission & 75 & 55 & 59 & 55 & 45 \\
Number of acceptance & 54 & 41 & 44 & 37 & 30 \\
Acceptance rate (\%) & 72 & 75 & 75 & 67 & 67 \\
Days to complete review & 53 & 75 & 55 & 44 & 33 \\
Publication lag time* & 221 & 151 & 139 & 93 & 141 \\
H5-index (Google Scholar) & na & 4 & 6 & 8 & 8 \\
H5-median (Google Scholar) & na & 6 & 8 & 9 & 11 \\
Local submission (\%) & 33 & na & na & 44 & 50 \\
International submission (\%) & 77 & na & na & 56 & 50 \\
\hline
\end{tabular}

Notes:

na: not available

*Number of days from submit to published

aData sourced until 31 December 2017

On behalf of the team, we look forward for this new journey and strongly believe the journal is soaring with Penerbit Universiti Sains Malaysia and MAEMHS as the key enablers towards becoming a premier journal in medical and health profession fields. It is noteworthy to mention that this journal is nowhere without the strong and relentless support from all stakeholders especially authors, reviewers, and readers. Last but not least, let us together taking part in this new journey! Your submissions are our priority.

\section{REFERENCES}

1. Yusoff MSB. Welcome to the Education in Medicine Journal. Education in Medicine Journal. 2010;2(1):e1. https://doi. org/10.5959/eimj.v2i1.91

2. Yusoff MSB. Visibility of Education in Medicine Journal. Education in Medicine Journal. 2014;6(1):e1-e2. https://doi. org/10.5959/eimj.v6i1.249
3. Yusoff MSB. Scientometric Properties of Education in Medicine Journal. Education in Medicine Journal. 2014; 6(3):e1-e4. https:// doi.org/10.5959/eimj.v6i3.289

4. Yusoff MSB. Soaring Upwards with USM Press. Education in Medicine Journal. 2015; 7(4):e1-e2. 